\title{
Media Coverage in Creating Environmental Awareness and its Impact on Environmental Behavior
}

\author{
Fitri Amalia Shintasiwi ${ }^{1}$, Wasino $^{2}$ \\ \{ shintasiwi@mail.unnes.ac.id ${ }^{1}$,wasino@mail.unnes.ac.id²\} \\ ${ }^{1,2}$ Universitas Negeri Semarang, Indonesia
}

\begin{abstract}
Globalization had a significant role in the society nowadays due to its rapid movement in spreading information around the world using several tools, such as mass media, so people can easily access information. Many people who are aware about environmental conservation start using mass media in campaigning the importance of environmental sustainability. Hence, the aim of this study is to identify the role of mass media such as television, newspaper, internet and social media in improving the people's awareness in maintaining the environmental changes because of ecological changes. The method of this study is qualitative method using interviews. Semi-structure interviews were conducted to 30 participants from three different categories including students, people living in the riverbanks and the general public. The results show that most students agree that mass media, especially internet and social media are effective in helping them to improve their awareness to decrease the consumption of plastic bags and straws, even they also used them to promote their organization related to environmental sustainability. However, only few people from the other categories feel that mass media that they access, especially television and internet, may change their behavior to reduce plastics or other conservation activities.
\end{abstract}

Keywords: Globalization, Conservation, Media, Sustainability, Awareness.

\section{Introduction}

As the impacts of industrialization and modernization in the global era, our earth is suffering. The environmental issues related global warming, green-house effect, air and water pollution, waste disposal, climate change and other issues which can be harmful for human and other living things in this planet become worrisome. People as an agent of change are supposed to make better environment for the future generation through several ways. One of them are campaigns in order to persuade people in preserving and maintaining environment through both traditional and modern platform (mass media and social media).

In fact, mass media can be accessed easily by almost people in the world nowadays. People can access and exchange information through varied media. That is why media has significant role to carry worthwhile messages to preserve environment, because people find information related to environment through this platform actively and easily [1]. Several environmental information can be spread through mass media such as television, newspaper and online newspaper, radio, etc. We may find the negative impact of climate change, for example, in the television news and Youtube, the news about dead sperm whales found in Indonesia and had ingested $6 \mathrm{~kg}$ of plastic. In addition, social media also has an important role to spread environmental information effectively because people tend to use them every day, 
and sometimes, they prefer to believe information from these online platforms rather than the offline one. It may be due to the fact that they are handy and easy to access through their personal gadget, namely mobile phone, laptop and tablet. In fact, social media they used can be Facebook, Whatsapp, Twitter, Instagram, Line, and others.

Thus, this paper aims to identify the role of mass media such as television, newspaper, internet and social media in improving the people's awareness in maintaining the environmental changes because of ecological changes in Indonesia. As we know that in Indonesia, many people tend to indifferent about the environmental condition in their surroundings. Therefore, after determining the effectiveness of media, this research is also trying to analyze whether the mass media and social media is effective in changing the people's perspective in doing environmental conservation into practice.

Moreover, this will be compared into the previous study evidenced that television documentaries aired on the local television and news broadcast are effective to increase the public awareness and the level of knowledge about environmental issues [2]. Furthermore, a quantitative study conducted in Japan society also agrees that the media can be exerted in notable influence related to public awareness and attitude by keeping considerable coverage of the environmental issues frequently [3]. However, another study shows that the positive effect of media may be useful in increasing their intention for reducing the cause of climate change, only for their individual economic benefit and for political interest, but it is not prevailing the long-term action [4].

\section{Research Methods}

Methods used in this research is qualitative by using interviews. This method was chosen in order to find in-depth information related to their perception of the use of mass media and social media in increasing their environmental awareness and then led to their behavior in maintaining good environment. The interviews include 30 participants from three different categories, namely college students, people living in the river banks and the general public. The respondents are female and male aged 20-50 years old: college students (18-22 years old), people living in the river banks (35-50 years old) and the general public (35-45 years old). Semi-structured interviews were used in this research, and the technique used is snowball sampling because I chose 10 random people for each category [5]. The respondents were selected because I will find out the differences of people's perspectives from three categories. The interviews were conducted in Universitas Negeri Semarang, several riverbanks in Central Java and Gunung Pati neighborhood. Additionally, the interviews were also conducted in relaxed situation, so the respondents may be open and answer the question comfortably. Then, the recording was transcribed, categorized and analyzed based on the mentioned problems above.

\section{Results}

Based on the interviews from the respondents, most of them do not deliberately access information related to the environment issues, they choose other issues, such as politics, entertainment, sports, food, travelling, fashion, etc. The respondents from the second (people living in the river banks) and third category (the general public) stated that they use television every day rather that other mass media, but most of them do not realize that they read information about environment because of the lack information related to this issue. When 
they were asked about the phenomena of 'the dead sperm whale' and other environmental issues, they seem not understand, and they said never heard about the issue before in the local channel. However, some of them know about the phenomenon, they said sorry, but they cannot do anything to avoid using plastics due to their own necessities. They also think that they cannot reduce their needs in using plastics in their life because it is cheap and easy to get. One of the respondents from the general public (R1) said that 'I am concerned, but it is very hard to avoid using plastics because it is handy and I need that every day. It is difficult for me to bring shopping bag anytime.' In addition, one of the respondents (R2) also said 'It is heartbreaking, but it is difficult [to reduce plastic bag].' Even, one of the respondents from the second category stated (R3):

I don't think that after watching news about the whales which were dead or other campaign [related to the environment issues] will change my behavior to use plastic bags. I am sad and feel pity about that, yeah, but I need [the plastic bags]. For me, it is difficult not using them. I think media doesn't affect me or people's behavior because it is based on their own eagerness.

However, it is interesting to say that for the first category, the college students are more aware about the positive function of mass media in reducing the use of plastics and the invitation in throwing garbage in the right place. They found information through online media, such as online newspaper and article, Youtube and other online platforms which provide the documentary about our current condition of environment or other issues related the gradual damage of our earth. They believe that the development of mass media nowadays may influence the increasing number of people who keep the environment clean and even socialize campaign in how to recycle garbage properly. One of the college students mentioned that 'online media may help people to recycle plastics into the high value products' (R4), '[mass media] are used to persuade people maintain the environment hygiene' (R5). In addition, they also notice some advertisement related to environmental conservation in the mass media. they said that it is effective for them to increase their environmental awareness indirectly, so they are triggered to do a positive behavior in conservation. One of the respondents stated (R6):

I think media have an important role for my life either printed or electronic media [because] they can persuade and stimuli me and my friends to throw garbage properly or to recycle them. And, they also help people how to use the recycle garbage or to sell them. I watch video on Youtube and read news that our earth is changing, and I am afraid of that. I hope people may be aware about our environment now.

From the interview, most of the college students suggested that the most effective media in campaigning environmental conservation for all people this digital era is social media, especially Facebook, Instagram and Whatsapp. This is due to the fact that people bring and use their phone every single minute to access internet easily. For instance, one of the college students (R7) said that they are moved to use stainless steel straw after persuaded by her friend to reduce plastic straw to maintain environment in the future. She also believed that youth as an agent of change. Some respondents also agree that social media that they use every single day lead them to be a better person in environment, and they are affected by a campaign shared by their colleagues and friends through social media. One of the respondents said (R8): 
After watching campaign about the steps to prevent the environmental issues, I realize [that] we are young, we can make change. Let's recycle our garbage, let's avoid using disposable plastic bags, let's reduce using plastic straw, let's clean our environment. Let's do everything for our future.

\section{Discussion}

As we know, mass media have three forms in this globalization era, such as printed media (newspaper, tabloid, magazine), electronic media and online media. Based on the interviews of the respondents, most of them used electronic media and online media in looking for information and news because they are considered as simple and easy to access. In addition, they are also affordable and based on the current development of media. In other words, based on the interviews, the respondents think that printed media are less effective nowadays. Therefore, we can say that the functions of mass media related to environmental conservation based on McQuail's descriptions [6] are to provide information about environmental issues, to develop and to campaign new culture in preserving environment, to educate people in increasing their environmental awareness and to persuade people in maintaining good environment for the future generation. Thus, it means that media have a significant role in changing or in building people's perception about the environmental awareness by delivering positive values, so people are triggered to start the possible action towards the environmental issued [7].

From the data in the results, we may say that the respondents from the first and second categories, namely people living in the river banks and the general public tend to still use plastics wastefully and do negative behavior for environment. However, in this case, if we connect into the concept of environmental awareness, it is only purely the cognitive construct, or it means that to identify whether someone is aware of the endangered environment or not $[8,9]$, so media actually have educated people to be understand the environmental situation now. In other hands, their behavior does not correspond with their cognition about the environment because of several factors, such as economic benefits and their own necessities. Furthermore, public awareness related environment sustainability can be achieved for some respondents in two categories, but some of them do not care about this situation because they do not access or watch the news or local TV programs related to the endangered environment. The lack information and promotion related to environmental conservation in local TV is the biggest problem which may cause the respondents are not aware of the issue.

In fact, the respondents from the third categories, college students, show their desires and interests in doing various actions to keep the environment clean and healthy, as well as reducing plastic use in our society. In other words, mass media and social media have a positive impact for the young people in implementing environmental action. Additionally, the rapid development of social media in this modern era also can accelerate the youth in promoting the campaign. This is in line with the concept of positive environmental action [10] that it is included various intentional actions in deciding, planning, implementing and reflecting their behavior to achieve positive outcome towards their surrounding environment. Moreover, they also understand their position as an agent of change, so they try to persuade other people through campaigns, especially to the youth in order to create positive environmental action [11], and "action creates change, whereas behavior may only perpetuate accepted norms" [12].

One of the suggestion to improve public awareness towards environmental sustainability is that the government should engage with the television broadcast to do campaign about 
environment. Television program related to the damage of environment should be aired frequently including various ways to maintain the environment effectively. Advertisement in social media and Youtube can be also effective. This is due to the fact that the media used by people aged 30-50 years old in the village are television. Furthermore, the government should increase the price of plastic bags and plastic straws drastically. It may decrease the consumption of them because they have to pay much money for purchasing plastics.

\section{Conclusion}

Mass media, especially electronic media and social media have an important role in changing people's perspective in maintaining the environmental sustainability. Most students agree that mass media, especially internet and social media are effective in helping them to improve their awareness to decrease the consumption of plastic bags and straws, even they also used them to promote their organization related to environmental conservation or to persuade other people doing so, in other words, as an agent of change. However, only few people from the other categories feel that mass media that they access, especially television and internet, may change their behavior to reduce plastics or other conservation activities to achieve environmental sustainability. But, they realize that the earth is still suffering from the endangered environment.

\section{References}

[1] Ostman, R.E. \& Parker, J.L.: Impact of education, age, newspapers, and television on environmental knowledge, concerns, and behaviors. The Journal of Environmental Education, 19 (1), 3-9 (1987).

[2] Brothers, C.C. \& Fortner, R.W. \& Mayer, V.J.: The impact of television news on public environmental knowledge. The Journal of Environmental Education, 22 (4), $22-$ 29 (1991).

[3] Mikami, S. \& Takeshita, T. \& Nakada, M. \& Kawabata, M.: The media coverage and public awareness of environmental issues in Japan. Gazette, 54, 209-226 (1995).

[4] Arlt, D. \& Hoppe, I.: Climate change and media usage: Effects on problem awareness and behavioral intentions. The International Communication Gazette, 73 (1-2), 45-63 (2011).

[5] Dörnyei Z.: Research methods in applied linguistics. Oxford: Oxford University Press (2007).

[6] McQuail, D.: McQuail's mass communication theory (6 ${ }^{\text {th }}$ edition). London: SAGE Publication (2010).

[7] Lance, H.R. \& Kwak, N. \& Shah, D.V.: Environmental concern, patterns of television viewing, and pro-environmental behaviors: Integrating models of media consumption and effects. Journal of Broadcasting and Electronic Media 47(2): 177-196 (2003).

[8] Matthies, E. \& Schahn: Umweltverhalten aus differentieller Perspektive: Diagnostik, Erkla“rung und Vera“nderung individuellen Umweltverhaltens. In: Pawlik K (ed.) Enzyklopa"die der Psychologie. Band V. Theorien und Anwendungen der Differentiellen Psychologie. Go"ttingen: Hogrefe, 685-740 J (2004).

[9] Nerb, J. \&Spada, H.: Evaluation of environmental problems: A coherence model of cognition and emotion. Cognition and Emotion 15(4): 521-551 (2001).

[10] Emmons, K. M.: Perspectives on environmental action: Reflection and revision through practical experience. The Journal of Environmental Education, 29 (1), 34-44 (1997). 
[11] Jensen, B. B., \& Schnack, K.: The action competence approach in environmental education. Environmental Education Research, 12, 471-486 (2006).

[12] Arnold, H.E. \& Cohen, F.G. \& Warner, A.: Youth and environmental action: Perspectives of young environmental leaders on their formative influences. The Journal of Environmental Education, 40 (3), 27-36 (2009). 